\title{
PENGARUH GAYA BELAJAR TERHADAP HASIL BELAJAR IPA
}

\section{INFLUENCE OF LEARNING STYLE ON THE STUDENTS SCIENCE LEARNING ACHIEVEMENT}

\author{
Ilfa Irawati' ${ }^{1}$, Nasruddin ${ }^{2}$, dan Mohammad Liwa Ilhamdi" \\ ${ }^{1}$ Mahasiswa S1 Program Studi Pendidikan Guru Sekolah Dasar FKIP Universitas Mataram. \\ ${ }^{2}$ Dosen Program Studi Pendidikan Guru Sekolah Dasar FKIP Universitas Mataram. \\ *Email:liwa_ilhamdi@unram.ac.id
}

Diterima16 November 2020. Disetujui: 27 November 2020. Dipublikasikan: 9 Januari 2021

\begin{abstract}
Abstrak: Tujuan penelitian ini yaitu untuk mengetahui pengaruh gaya belajar terhadap hasil belajar IPA siswa kelas IV SDN 9 Mataram. Jenis penelitian ini adalah ex post facto dengan desain penelitian kausal komparatif. Teknik pengumpulan data yang digunakan adalah angket tertutup untuk variabel gaya belajar dan dokumentasi untuk mengumpulkan data hasil belajar. Subjek penelitian sebanyak 70 responden yaitu siswa kelas IV SDN 9 Mataram yang diperoleh dengan teknik sampling jenuh. Data dianalisis menggunakan statistik deskriptif dan analisis statistik inferensial yaitu uji regresi sederhana. Hasil penelitian menunjukkan gaya belajar siswa kelas IV SDN 9 Mataram lebih cenderung memiliki gaya belajar visual dengan jumlah 33 siswa, persentase sebesar 47.14\% yang termasuk dalam kategori cukup. Hasil belajar IPA siswa yang dilihat dari nilai Ulangan Akhir Semester (UAS) menunjukkan bahwa sebagian besar hasil belajar siswa kelas IV pada mata pelajaran IPA berada pada kategori sedang yaitu dicapai oleh 32 siswa dengan persentase $45.72 \%$. Berdasarkan analisis data dengan taraf signifikansi $5 \%$ diperoleh nilai $t_{\text {hitung }}>t_{\text {tabel }}$ yaitu $4.288>1.995$. Apabila dilihat dari nilai signifikansinya yaitu sig. $0.000<0.05$. Dengan demikian maka dapat disimpulkan ada pengaruh signifikan gaya belajar terhadap hasil belajar IPA kelas IV SDN 9 Mataram. Gaya belajar memberikan kontribusi terhadap hasil belajar sebesar 21.2\%.
\end{abstract}

Kata Kunci: Gaya belajar, hasil belajar siswa, IPA.

\begin{abstract}
The purpose of this study was to determine the effect of learning styles on science learning outcomes of fourth grade students of SDN 9 Mataram. This type of research is ex post facto with a comparative causal research design. The data collection technique used was a closed questionnaire for learning style variables and documentation to collect learning outcome data. The research subjects were 70 respondents, namely fourth grade students of SDN 9 Mataram obtained by saturated sampling technique. The collected research data were then analyzed using descriptive statistics and inferential statistical analysis, namely simple regression tests. The results showed that the learning styles of the fourth grade students of SDN 9 Mataram were more likely to have a visual learning style with a total of 33 students, a percentage of $47.14 \%$ which was included in the sufficient category. Students 'science learning outcomes as seen from the final semester test scores (UAS) show that most of the fourth grade students' learning outcomes in science subjects are in the medium category, which is achieved by 32 students with a percentage of $45.72 \%$. Based on data analysis with a significance level of $5 \%$, the value of tcount $>$ ttable is $4.288>1.995$. When viewed from the significance value, namely sig. $000<0.05$. Thus, it can be concluded that Ho is rejected and $\mathrm{Ha}$ is accepted, which means that there is a significant effect of learning styles on science learning outcomes in grade IV SDN 9 Mataram. Learning styles contributed 21.2\%.
\end{abstract}

Keywords: Learning style, learning outcomes, natural sciences.

\section{PENDAHULUAN}

Pendidikan dianggap mempunyai peranan yang penting dalam pencerminan karakter suatu bangsa. Pendidikan menjadi suatu akses yang sesuai untuk mengembangkan potensi yang ada dalam diri manusia. Pendidikan tidak hanya beriorentasi pada peningkatan dalam bidang akademik tetapi non akademik juga perlu diperhatikan. Pendidikan dilakukan secara menyeluruh dalam pengembangan intelektual maupun kepribadian anak [1]. Salah satu bentuk menempuh pendidikan adalah dengan belajar di sekolah sesuai dengan jenjangnya. Salah satunya yaitu pendidikan Sekolah Dasar (SD). Pedoman yang digunakan dalam melaksanakan proses belajar mengajar adalah kurikulum. Pelaksanaan pembelajaran di sekolah harus sesuai dengan kurikulum yang ditetapkan oleh pemerintah sebagai kurikulum nasional. Kurikulum yang diterapkan di SD saat ini adalah kurikulum 2013. Kurikulum di sekolah berisi muatan mata pelajaran, sebagaimana tercantum dalam Peraturan Menteri Pendidikan dan Kebudayaan Republik Indonesia Nomor 57 Tahun 2014 tentang kurikulum 2013 Sekolah Dasar/Madrasah Ibtidaiyah pasal 5 ayat 6 termuat mata pelajaran kelompok A terdiri atas enam muatan pelajaran, salah satunya muatan pelajaran Ilmu Pengetahuan Alam (IPA).

IPA adalah pengetahuan yang rasional dan objektif tentang alam semesta dengan segala isinya. Rasional artinya masuk akal atau logis, diterima oleh akal sehat. Objektif artinya sesuai dengan objeknya, sesuai dengan kenyataan atau sesuai dengan 
pengalaman pengamatan melalui panca indera. Pembelajaran IPA bertujuan untuk mengembangkan pengetahuan dan konsep IPA yang bermanfaat dan dapat diterapkan dalam kehidupan, serta untuk meningkatkan kesadaran peserta didik agar ikut serta dalam menjaga, memelihara, melestarikan, dan menghargai alam sekitar sebagai salah satu ciptaan Tuhan [2]. Pembelajaran IPA disekolah dasar sebaiknya difokuskan pada kemampuan berfikir dan keterlibatan siswa secara aktif dalam proses pembelajaran. Bentuk nyata dari keberhasilan suatu proses pembelajaran IPA dapat dilihat dari hasil belajar yang didapatkan oleh siswa.

Hasil belajar diartikan sebagai tingkat keberhasilan siswa dalam mempelajari materi pelajaran di sekolah yang dinyatakan dalam bentuk skor yang diperoleh dari hasil tes mengenal sejumlah materi pelajaran tertentu [3]. Hasil belajar pada hakekatnya adalah perubahan suatu tingkah laku seseorang sebagai hasil dari proses belajar. Perubahan tersebut dapat berupa pengetahuan, pemahaman, keterampilan dan sikap yang biasanya dinyatakan dalam bentuk angka ataupun lambang huruf dengan kriteria-kriteria yang telah ditentukan. Hasil belajar yang diperoleh siswa dapat memberikan informasi tentang kemampuan siswa dalam memahami materi pembelajaran yang dijelaskan oleh guru dalam proses belajar mengajar di kelas.

Setiap individu sering kali harus menempuh cara berbeda untuk bisa memahami sebuah informasi atau pelajaran yang sama [4]. Hal ini disebut sebagai gaya belajar atau modalitas belajar. Gaya belajar merupakan cara seseorang merasa mudah, nyaman, dan aman saat belajar, baik dari sisi waktu maupun secara indra. Modalitas belajar yang paling popular dan dikenal hingga sekarang adalah modalitas atau gaya belajar VAK yaitu gaya belajar Visual, Auditory, dan Kinestetik [5].

Gaya belajar Visual adalah gaya belajar dengan cara melihat sehingga mata memegang peranan penting. Adapun karakteristik seseorang yang menggunakan Visual Learning, diantaranya: Materi pelajaran harus yang dapat dilihat, saat proses KBM ia akan berusaha duduk didepan kelas, suka mencoret-coret sesuatu yang terkadang tanpa ada artinya saat di dalam kelas,pembaca cepat dan tekun, lebih suka membaca daripada dibacakan, lebih menyukai peragaan daripada penjelasan lisan, Mempunyai masalah untuk mengingat instruksi verbal, harus melihat bahasa tubuh dan ekspresi muka gurunya untuk mengerti materi pelajaran, rapi dan teratur [6].

Gaya belajar auditori yaitu gaya belajar yang dilakukan seseorang untuk memperoleh informasi dengan memanfaatkan indra pendengarannya. Adapun karakteristik seseorang yang menggunakan Auditory Learning, diantaranya: Ia akan mencari posisi duduk tempat dia dapat mendengar meskipun tidak dapat melihat yang terjadi didepannya, ketika merasa bosan biasanya berbicara dengan diri sendiri atau teman disampingnya atau bisa juga dengan menyanyikan sebuah lagu, materi pembelajaran yang dipelajari akan mudah dipahami jika dibaca nyaring, lebih cepat menyerap dengan mendengarkan, dapat mengingat dengan baik materi saat diskusi, senang membaca dengan suara keras, dapat menghafal lebih cepat dengan membaca teks dengan keras dan mendengarkan kaset, senang diskusi, bicara, bertanya, atau menjelaskan sesuatu dengan panjang, suka mengerjakan tugas kelompok, merasa terganggu jika ada teman yang berbicara ketika sedang memperhatikan guru menjelaskan materi [7].

Gaya belajar kinestetik merupakan cara belajar yang dilakukan seseorang untuk memperoleh informasi dengan melakukan pengalaman, gerakan, dan sentuhan. Selain itu, belajar secara kinestetik berhubungan dengan praktik atau pengalaman belajar secara langsung.Adapun karakteristik seseorang yang menggunakan Kinesthetic Learning, diantaranya: Ketika menyampaikan pendapat biasanya disertai dengan gerakan tangan atau bahasa tubuh yang melibatkan anggota tubuh lain seperti wajah, mata, dan sebagainya, ketika merasa bosan akan pergi atau berpindah tempat, menyenangi materi pembelajaran yang bersifat mempraktikkan, gemar menyentuh segala sesuatu yang dijumpainya, suka menggunakan objek nyata sebagai alat bantu belajar, berbicara dengan perlahan, belajar melalui praktik, banyak menggunakan isyarat tubuh, kemungkinan tulisannya jelek, menyukai permainan olahraga [7]. Walaupun masing-masing siswa belajar dengan menggunakan ketiga gaya belajar ini, kebanyakan siswa lebih cenderung pada salah satu diantara gaya belajar tersebut.

Kemampuan siswa untuk memahami dan menyerap informasi tentunya berbeda-beda tingkatnya [8]. Ada yang cepat, sedang, dan lambat, karena itulah siswa sering kali harus menempuh cara yang berbeda-beda untuk bisa memahami setiap informasi [9]. Ketika siswa sudah memahami gaya belajarnya sendiri, maka siswa tersebut dapat memproses materi pelajaran atau informasi dengan baik dan masuk ke dalam ingatan jangka panjang.

Berdasarkan hasil wawancara yang peneliti lakukan dengan guru kelas IV SDN 9 Mataram diperoleh keterangan bahwa siswa terkadang mengalami kesulitan memahami materi yang dijelaskan oleh guru, sehingga sering bertanya kembali kepada teman sebayanya, terdapat siswa yang juga sulit memahami materi apabila tidak diberikan contoh atau dituliskan pada papan tulis, terdapat siswa yang sulit memahami materi apabila tidak mendengarkan ketika guru sedang menjelaskan materi, terdapat juga siswa yang tidak tahan duduk berlama-lama dan ingin selalu bergerak agar mampu memahami materi. Guru juga mengatakan dalam penyampaian materi tidak selalu menggunakan bantuan alat peraga dalam penyampaian materi, dan lebih memanfaatkan ketersediaan sumber buku yang 
tersedia di sekolah untuk mendukung kegiatan belajar mengajar.

Setiap kegiatan pembelajaran tentunya selalu mengharapkan akan menghasilkan pembelajaran yang maksimal [10]. Pentingnya bagi seorang guru untuk mengetahui karakter atau gaya belajar yang disukai oleh siswa, agar guru akan lebih efektif dalam memilih strategi atau metode pembelajaran yang akan digunakan untuk menyampaikan materi, sehingga materi akan dapat tersampaikan dengan baik kepada siswa yang memiliki gaya belajar yang berbeda-beda serta siswa akan dapat memperoleh hasil belajar yang lebih optimal.

Berdasarkan uraian di atas, maka peneliti tertarik untuk melakukan penelitian yang berjudul pengaruh gaya belajar terhadap hasil belajar IPA siswa kelas IV SDN 9 Mataram. Rumusan masalah dalam penelitian ini adalah apakah ada pengaruh gaya belajar terhadap hasil belajar IPA siswa kelas IV SDN 9 Mataram. Adapun tujuan dalam penelitian ini adalah untuk mengetahui pengaruh gaya belajar terhadap hasil belajar IPA siswa kelas IV SDN 9 Mataram.

\section{METODE PENELITIAN}

Penelitian ini termasuk ke dalam penelitian kuantitatif, jenis penelitian ini adalah ex post facto dengan desain penelitian kausal komparatif, karena bermaksud mengidentifikasi pengaruh variabel $\mathrm{X}$ terhadap variabel Y. Pendekatan dasar kausal komparatif melibatkan kegiatan peneliti yang diawali dari mengidentifikasi pengaruh variabel satu terhadap variabel lainnya, kemudian dia berusaha mencari kemungkinan variabel penyebabnya [11]. Variabel independen (X) dalam penelitian ini adalah Gaya Belajar siswa. Variabel dependen (Y) dalam penelitian ini adalah Hasil Belajar IPA kelas IV SDN 9 Mataram. Penelitian ini dilaksanakan di SDN 9 Mataram pada semester ganjil Tahun Pelajaran 2020/2021 dengan populasi siswa kelas IV dengan jumlah 70 siswa. Dalam penelitian ini teknik sampling yang digunakan adalah Sampling jenuh yaitu teknik penentuan sampel bila semua anggota populasi digunakan sebagai sampel [12].

Metode pengumpulan data yang digunakan dalam penelitian ini adalah kuesioner (angket) tertutup diberikan kepada siswa untuk mengetahui berbagai macam gaya belajarnya. Angket tertutup adalah pertanyaan-pertanyaan yang sudah disediakan jawabannya. Sehingga responden bisa memilih jawaban yang telah disediakan [13]. Dokumentasi juga digunakan untuk mengumpulkan data hasil belajar IPA siswa kelas IV SDN 9 Mataram. Instrumen penelitian yang digunakan meliputi angket gaya belajar dengan jumlah 39 item pernyataan yang terdiri dari aspek gaya belajar visual, auditori, dan kinestetik yang sudah melalui uji validitas ahli (expert judgment).

Data yang diperoleh dianalisis dengan menggunakan analisis statistik deskriptif yang bertujuan untuk mengetahui kecenderungan gaya belajar siswa dengan menggunakan rumus sebagai berikut:

$$
P=\frac{F}{N} X 100 \%
$$

Keterangan:

$\mathrm{P}=$ Persentase

$\mathrm{F}=$ Frekuensi

$\mathrm{N}=$ Jumlah subyek

Setelah dilakukan penghitungan skor, maka dilakukan penggolongan kecenderungan gaya belajar siswa dengan berpedoman pada tabel kriteria penilaian lima kategori [14], yang dapat dilihat pada tabel di bawah ini:

Tabel 1. Pedoman Kategori Persentase Kecenderungan Gaya Belajar

\begin{tabular}{cc}
\hline Kategori & Rentang Persentase \\
\hline sangat baik & $81 \%-100 \%$ \\
Baik & $61 \%-80 \%$ \\
Cukup & $41 \%-60 \%$ \\
Kurang & $21 \%-40 \%$ \\
kurang sekali & $0 \%-20 \%$ \\
\hline
\end{tabular}

Selanjutnya dilakukan uji prasyarat yaitu uji normalitas dilakukan untuk mengetahui apakah data berdistribusi normal atau tidak, data dapat dikatakan normal apabila nilai signifikansi (Sig.) lebih besar dari 0.05 pada taraf signifikansi 5\%. Jika nilai signifikansi (Sig.) lebih kecil dari 0.05 pada taraf signifikansi $5 \%$ maka data penelitian dikatakan tidak berdistribusi normal. Selain uji normalitas, dilakukan juga uji linieaitas untuk mengetahui hubungan antara variabel bebas dengan variabel terikat berbentuk linear atau tidak [15]. Data dapat dikatakan liniear apabila nilai signifkansi lebih besar dari 5\% atau 0.05 . Sedangkan sebaliknya apabila nilai signifikansi lebih kecil dari 5\% atau 0.05 maka hubungan variabel bebas terhadap variabel terikat tidak liniear.

Analisis regresi sederhana digunakan untuk menganalisis pengaruh gaya belajar terhadap hasil belajar IPA siswa kelas IV SDN 9 Mataram [16]. Analisis tersebut dilakukan dengan bantuan Program SPSS versi 23.

\section{HASIL DAN PEMBAHASAN}

Gaya belajar merupakan suatu cara seseorang merasa mudah dan nyaman saat menyerap, mengatur dan memahami informasi sehingga mempengaruhi hasil belajar siswa. Hasil penelitian yang dilakukakn di SDN 9 Mataram bahwa siswa kelas IV cenderung memiliki gaya belajar visual, hal tersebut dilihat dari data hasil angket yang diperoleh. Diketahui bahwa siswa dengan jumlah 33 siswa memiliki gaya belajar visual dengan persentase sebesar $47.14 \%$ yang termasuk dalam kategori cukup. Selanjutnya, siswa dengan jumlah 19 memiliki gaya belajar kinestetik dengan persentase sebesar $27.14 \%$ termasuk kedalam 
kategori kurang. Siswa dengan jumlah 18 memiliki gaya belajar auditori dengan persentase sebesar $25.72 \%$ termasuk dalam kategori kurang.

Gaya belajar visual merupakan cara/gaya belajar dengan mengutamakan indera penglihatan [17]. Gaya belajar secara visual dilakukan seseorang untuk memperoleh informasi dengan cara melihat gambar, diagram, peta, poster, grafik, dan bisa juga dengan melihat data teks seperti tulisan dan huruf. Hal ini selaras dengan teori perkembangan menurut Piaget yaitu siswa sekolah dasar masih berada pada tahap operasional konkret (umur 7-11 tahun). Dimana mereka akan cepat memahami atau menyerap informasi dengan cara melihat objek secara langsung [18].

Berdasarkan data hasil belajar siswa yang diperoleh dari nilai Ulangan Akhir Semester (UAS) semester genap kelas IV tahun 2019/2020 diperoleh bahwa siswa yang memiliki gaya belajar visual memiliki hasil belajar lebih tinggi dibandingkan dengan siswa dengan gaya belajar auditori maupun kinestetik, yaitu dengan rata-rata sebesar 84.91.

Uji prasyarat yang dilakukan menunjukkan bahwa data berdistribusi normal dan liniear hal ini dapat diketahui dari nilai uji normalitas diperoleh nilai sig. gaya belajar sebesar 0.200 dan hasil belajar sebesar 0.200 . Hasil nilai sig. (2-tailed) > 0.05 yang dapat disimpulkan bahwa data berdistribusi normal. Kemudian dari hasil uji liniearitas diperoleh nilai sig. 0.426 dengan taraf signifikansi 0.05. Karena signifikansi $0.426>0.05$, maka hubungan antara gaya belajar terhadap hasil belajar adalah liniear.

Tabel 2. Uji Hipotesis

\begin{tabular}{lllllll}
\hline Model & $\begin{array}{l}\text { Koefisien } \\
\text { Regresi }\end{array}$ & $\mathbf{R}$ & $\mathbf{T}_{\text {hitung }}$ & $\mathbf{T}_{\text {tabel }}$ & Sig. & Kesimpulan \\
\hline $\begin{array}{l}\text { Konstanta } \\
\text { Gaya Belajar }\end{array}$ & $\begin{array}{l}57,970 \\
0,244\end{array}$ & 0,459 & 4,288 & 1,955 & 0,000 & Signifikan \\
\hline
\end{tabular}

Berdasarkan hasil pengujian hipotesis pada tabel di atas, diketahui bahwa gaya belajar memiliki hubungan positif dengan hasil belajar, dengan nilai koefisiennya sebesar 0.459. Artinya semakin meningkat gaya belajar siswa maka semakin meningkat hasil belajarnya. Pada tabel diatas juga dapat diketahui persamaan regresi gaya belajar terhadap hasil belajar siswa pada mata pelajaran IPA yaitu sebesar $\mathrm{Y}=57.970+0.244 \mathrm{X}$. Persamaan tersebut mengandung makna bahwa konstanta $(\alpha)$ sebesar 57.970 berarti bahwa jika skor gaya belajar sebesar nol maka besarnya hasil belajar siswa adalah 57.970. Koefisien regresi variabel gaya belajar sebesar 0.244 menjelaskan bahwa setiap gaya belajar meningkat sebesar satu satuan maka akan menyebabkan peningkatan atau kenaikan hasil belajar siswa sebesar 0.244 satuan.

Nilai sig. diperoleh sebesar 0.000 yaitu lebih kecil dari 0.05 , maka dapat disimpulkan bahwa Ho ditolak dan Ha diterima yang berarti ada pengaruh signifikan gaya belajar terhadap hasil belajar IPA kelas IV SDN 9 Mataram. Koefisien determinasi gaya belajar yang didapat melalui perhitungan yaitu $\mathrm{R}^{2} \times 100 \%=(0.461 \times 0.461) \times 100 \%=21,2$ yang berarti gaya belajar memberikan kontribusi terhadap hasil belajar sebesar $21.2 \%$.

Kecenderungan seseorang untuk belajar sangat beragam dan dipengaruhi oleh beberapa hal. Gaya belajar memegang peran yang penting dalam kegiatan pembelajaran. Penggunaan gaya belajar yang sesuai akan membantu siswa dalam proses belajar sehingga siswa mudah menyerap dan memahami informasi yang diterima [19]. Proses belajar merupakan suatu kegiatan yang dilakukan oleh siswa, tetapi di dalam memperoleh hasil belajar setiap siswa memiliki perbedaan, hal ini terjadi disebabkan oleh beberapa factor baik itu faktor internal atau factor dari dalam diri siswa, maupun factor eksternal atau factor yang berasal dari luar siswa. Dalam proses belajar factor yang lebih mempengaruhi yaitu factor yang ada dalam diri siswa karena sangat erat hubungannya dengan diri siswa tersebut, salah satunya yaitu gaya belajar.

Siswa yang dapat memaksimalkan gaya belajar yang dimiliki dalam proses menyerap informasi saat belajar akan mempengaruhi hasil belajar yang diperoleh. Gaya belajar merupakan cara tersendiri yang diterapkan oleh siswa pada kegiatan pembelajaran demi mencapai tujuan dari belajar. Jika siswa akrab dengan gaya belajar mereka sendiri, maka siswa dapat mengambil langkah-langkah penting untuk membantu diri siswa belajar lebih cepat dan lebih mudah [20]. Terdapat tiga tipe gaya belajar yaitu visual, auditori, dan kinestetik [21]. Gaya belajar visual adalah gaya belajar dengan cara melihat sehingga bagi siswa yang bergaya belajar visual, mereka akan mengandalkan indera penglihatan (mata). Gaya belajar visual adalah belajar dengan cara melihat sesuatu baik itu melalui gambar, diagram, pertunjukkan, peragaan, atau video. Pemberian informasi melalui gambar atau diagram merupakan stimulus dalam gaya belajar visual sebagai respon dari gaya belajar visual ini adalah hasil belajar yang diperoleh siswa yang memiliki gaya belajar visual tersebut. Gaya belajar visual membantu siswa untuk mengingat materi 
pelajaran yang langsung dilihat sehingga hal tersebut berpengaruh terhadap hasil belajar yang diperoleh. Teori di atas mendukung hasil penelitian ini, di mana siswa kelas IV di SDN 9 Mataram lebih cenderung memiliki gaya belajar visual dengan jumlah siswa 33 dengan persentase sebesar $47.14 \%$ dan rata-rata hasil belajar sebesar 84.91 .

Gaya belajar auditori yaitu gaya belajar yang dilakukan siswa untuk memperoleh informasi dengan memanfaatkan indra pendengarannya, siswa dengan gaya belajar auditori lebih mudah mengolah informasi dengan mendengarkan secara lisan. Dengan gaya belajar auditori, menyerap dan mengolah informasi dengan kemampuan mendengar yang baik akan menghasilkan hasil belajar yang baik pula. Gaya belajar kinestetik merupakan gaya belajar yang dilakukan seseorang untuk memperoleh informasi dengan melakukan pengalaman, gerakan, dan sentuhan. Siswa dimungkinkan untuk mencapai hasil belajar yang efektif melalui gerakan dan sentuhan secara langsung berdasarkan cirri gaya belajar kinestetik. Bagi siswa yang memiliki gaya belajar kinestetik kondisi fisik merupakan salah satu factor yang sangat penting, karena mereka akan langsung melakukan tindakan secara fisik dalam kegiatan belajar mereka. Jika mereka belajar dengan kondisi yang sehat, proses dan hasilnya akan maksimal.

\section{KESIMPULAN}

Berdasarkan hasil penelitian, analisis data, dan pembahasan yang telah diuraikan sebelumnya maka dapat disimpulkan bahwa persamaan regresi gaya belajar terhadap hasil belajar siswa pada mata pelajaran IPA sebesar $\mathrm{Y}=57.970+0.244 \mathrm{X}$. Hasil nilai signifikansinya yaitu sig. $0.000<0.05$ maka dapat disimpulkan bahwa Ho ditolak dan Ha diterima yang berarti ada pengaruh signifikan gaya belajar terhadap hasil belajar IPA kelas IV SDN 9 Mataram. Gaya belajar memberikan kontribusi terhadap hasil belajar IPA siswa kelas IV SDN 9 Mataram sebesar $21.2 \%$

\section{DAFTAR PUSTAKA}

[1] Dimyati, \& Mudjiono. (2015). Belajar \& Pembelajaran. Jakarta: PT. RINEKA CIPTA.

[2] Samatowa, U. (2016). Pembelajaran IPA di Sekolah Dasar. Jakarta: PT Indeks.

[3] Susanto, A. (2013). Teori Belajar \& Pembelajaran. Jakarta: Prenada Media Group.

[4] Suyono, A. (2018). Pengaruh Gaya Belajar Terhadap Hasil Belajar Pada Mata Pelajaran Akuntansi Kelas XI IPS SMA N 3 Tapung Tahun Ajaran 2017/2018. Jurnal Pendidikan Ekonomi Akuntansi FKIP UIR, 6 (1). 1-10.

[5] Subini, N. (2017). Rahasia Gaya Belajar Orang Besar. Yogyakarta: Javalitera.

[6] Nurhasanah. (2016). Pengaruh Gaya Belajar Terhadap Prestasi Belajar Matematika Siswa
Kelas VII SMP Yapis Manokwari.Prosiding Seminar Nasional, 02 (1), 173-182.

[7] Anas, A., Munir, N.P. Pengaruh Gaya Belajar VAK Terhadap Hasil Belajar Matematika Siswa. Prosiding Seminar Nasional, 02 (1). 233-240.

[8] Sugiarto, E., Hartono, H., \& Subandowo, S. (2020). Pengaruh Penggunaan Model Pembelajaran Pratikum Melalui Pendekatan Discovery Berbasis Inkuiri dan Gaya Kognitif Terhadap Hasil Belajar Siswa. Jurnal Pijar Mipa, 15(2), 182-187.

[9] Rahman, A. A., Yanti, S. (2016). Pengaruh Gaya Belajar Terhadap Hasil Belajar Siswa Pada Mata Pelajaran IPS Terpadu di Kelas VII SMP Negeri 1 Peudada. Jurnal Pendidikan Almuslim, IV (2), 1-6.

[10] Sudjana, N. (2010). Proses dan Hasil Belajar. Jakarta: Bumi Aksara.

[11] Darmadi, H. (2014). Metode Penelitian Pendidikan dan Sosial. Bandung: Alfabeta.

[12] Sugiyono. (2018). Metode Penelitian Kuantitatif, Kualitatif, dan R\&D. Bandung: Alfabeta.

[13] Arikunto, S. (2013). Prosedur Penelitian, Suatu Pendekatan Praktik. Jakarta: Rineka Cipta.

[14] Pujiarti, A. (2013). Hubungan antara gaya belajar dengan prestasi belajar siswa kelas V SD Negeri Percobaan 4 Wates Kulon Progo Tahun Ajaran 2012/2013. Fakultas Ilmu Pendidikan Universitas Negeri Yogyakarta.

[15] Siregar, S. (2014). Statistik Parametrik Untuk Penelitian Kuantitatif. Jakarta: PT. Bumi Aksara.

[16] Riduwan. (2013). Belajar Mudah Penelitian untuk Guru-Karyawan dan Peneliti Pemula. Bandung: ALFABETA.

[17] Bire, A. L., Geradus, U., \& Bire, J. (2014). Pengaruh Gaya Belajar Visual, Auditorial, dan Kinestetik Terhadap Prestasi Belajar Siswa. JURNAL KEPENDIDIKAN, 44 (2), 168-174.

[18] Husamah, dkk. (2018). Belajar \& Pembelajaran. Malang: Universitas Muhammadiyah Malang.

[19] Hasanah, I., Kantun, S., \& Djaja, S. (2018). Pengaruh Gaya Belajar Terhadap Hasil Belajar Siswa Kelas XI Jurusan Akuntansi Pada Kompetensi Dasar Jurnal Khusus Di SMK Negeri 1 Jember Semester Genap Tahun Ajaran 2017/2018. Jurnal Pendidikan Ekonomi, 12 (2), 277-282.

[20] Susilo, M. J. (2009). Sukses Dengan Gaya Belajar. Yogyakarta: Pinus.

[21] Chania, Y., Haviz, M., \& Sasmita, D., (2016). Hubungan Gaya Belajar dengan Hasil Belajar Siswa Pada Mata Pelajaran Biologi Kelas X SMAN 2 Sungai Tarab Kabupaten Tanah Datar. Journal of Sainstek, 8 (1), 77-84. 